\title{
Przesłanki odpowiedzialności za naruszenie obowiązków wynikających z pozwolenia na broń palną
}

\author{
RAFAL MIKOWSKI \\ ORCID: 0000-0002-9465-8510 \\ Zakład Prawa Administracyjnego Instytutu Nauk Administracyjnych \\ Wydział Prawa, Administracji i Ekonomii Uniwersytetu Wrocławskiego
}

\section{Zagadnienia wprowadzające}

W obowiązujących regulacjach prawnych dotyczących dostępu do broni palnej można zauważyć dążenie ustawodawcy do minimalizowania ryzyka wystąpienia sytuacji oddziałujących na społeczny odbiór wartości związanych $\mathrm{z}$ bezpieczeństwem — zarówno w skali makro, jak i indywidualnych odczuć. Sytuacja administracyjnoprawna jednostki ubiegającej się o pozwolenie na broń ${ }^{1}$ to dopiero początek drogi do zagwarantowania bezpiecznego wejścia $\mathrm{w}$ posiadanie i posługiwanie się bronią palną. Tak naprawdę dopiero otrzymanie decyzji administracyjnej,

${ }^{1}$ Opracowanie zostanie poprowadzone w kontekście okoliczności faktycznych wzbudzających odpowiedzialność prawną jednostki posiadającej pozwolenie na broń. W rozważaniach pominięta zostanie ta sfera regulacji prawnych, które dotyczą instytucjonalnego zakresu problematyki, związanego z posiadaniem broni palnej przez służby, inspekcje i straże oraz inne podmioty o charakterze zorganizowanego bytu prawnego. Zob. R. Mikowski, Kilka uwag o podstawach prawnych ograniczeń dostępu do broni palnej w Polsce, ,Przegląd Prawa i Administracji” 115, 2018, s. 163-174. 
jaką jest pozwolenie na broń ${ }^{2}$, otwiera szeroki wachlarz uprawnień oraz obowiązków stawiających osobę uprawnioną przed licznymi dylematami prawnymi związanymi z prawidłowym i legalnym używaniem broni. Już w momencie określenia przesłanek pozytywnych wydania pozwolenia na broń uwidacznia się sposób pojmowania przez ustawodawcę działań, które mają wpływać na gwarantowanie bezpieczeństwa obywatelom, poprzez oddziaływanie także na świadomość jednostki, że obecność broni ${ }^{3}$ w społeczeństwie jest w najwyższym stopniu ograniczona i nie przekracza niezbędnego minimum.

Próba syntetycznego zidentyfikowania katalogu sytuacji mogących rzutować na bezpieczeństwo i porządek publiczny w badanym przedmiocie pozwoliłaby ocenić działania państwa w sferze gwarancji prawnych bezpieczeństwa fizycznego związanego z dostępem do broni palnej przez obywateli polskich w granicach terytorialnych państwa ${ }^{4}$. Należy przy tym spróbować ustalić, czy wszystkie potencjalnie niebezpieczne sytuacje związane z posiadaniem broni palnej łączą się wyłącznie z czynami zabronionymi, penalizowanymi w kodeksie karnym, polegającymi na popełnieniu przestępstwa przy użyciu broni palnej. A zatem czy katalog przesłanek powodujących odpowiedzialność za naruszenia w badanym przedmiocie wpływa na proporcję w zakresie odpowiedzialności administracyjnej i odpowiedzialności karnej? Dodatkowo czy (jeżeli istnieje) tożsamość okoliczności uzasadniających prawną reakcję państwa pociąga za sobą lub wyklucza korzystanie zarówno z administracyjnoprawnych, jak i karnoprawnych instrumentów, efektywnie przyczyniających się do wykluczenia niepożądanych postaw oraz osób ze stosunków społecznych w danej płaszczyźnie? Z tego też powodu konieczne wydaje się ustalenie okoliczności powodujących naruszenie reguł prawidłowego

2 Zob. P. Podsiedlik, Zagadnienia administracyjno-prawne posiadania broni palnej w Polsce. Charakterystyka prawa posiadania broni palnej, Katowice 2010, s. 34.

3 Zob. T. Hanausek, Problem ,niebezpieczności” broni palnej, „Państwo i Prawo” 2001, nr 6, s. 72-74. Należy przy tym zwrócić uwagę, że ustawodawca w definicji broni nie akcentuje jej niebezpieczności, co nie przesądza o niewystępowaniu takiej cechy; por. R. Rejmaniak, Pojęcie broni palnej, „Prokuratura i Prawo” 2018, nr. 4, s. 78-103.

${ }^{4} \mathrm{Z}$ uwagi na obszerny zakres analizowanej problematyki do odrębnego opracowania zostaną wyłączone zagadnienia dotyczące cudzoziemców przebywających na terytorium RP oraz przemieszczenie broni poza granice RP. 
posiadania broni palnej, które będą wpływały na sytuację prawną osoby mającej pozwolenie na broń. Podnoszenie takiego przekonania obywateli wyprowadzane jest wielokrotnie z idei państwa opiekuńczego, które tylko na zasadzie subsydiarności dopuszcza wyjątek od stawiania się w roli strażnika bezpieczeństwa, pojmując obowiązki władz publicznych w tym zakresie także jako działania polegające na wprowadzaniu ograniczeń w korzystaniu z praw i wolności ${ }^{5}$.

\section{Bezpieczeństwo fizyczne broni - ochrona przed dostępem osób nieuprawnionych}

Ustawodawca, nakładając na posiadacza broni obowiązek należytego zabezpieczenia broni, przewiduje odpowiedzialność prawną w sytuacji naruszenia zasad przechowywania broni określonych $\mathrm{w}$ art. 32 ustawy z dnia 21 maja 1999 roku o broni i amunicjí ${ }^{6}$. Przesłanka odpowiedzialności w takim wypadku zostaje spełniona, jeżeli posiadacz broni nie zabezpieczy jej przed dostępem osób nieuprawnionych. Przeciwdziałać takim sytuacjom mają regulacje dotyczące między innymi wymogów stosowania urządzeń do przechowywania broni. Zgodnie z rozporządzeniem Ministra Spraw Wewnętrznych z dnia 26 sierpnia 2014 roku w sprawie przechowywania, noszenia oraz ewidencjonowania broni i amunicji ${ }^{7}$ broń i amunicję przechowuje się w odpowiednio przystosowanych magazynach broni lub w urządzeniach ${ }^{8}$ spełniających wymagania co najmniej klasy S1 według normy PN-EN 14450. Broń na czas przechowywania musi mieć odłączony magazynek oraz nie może być załadowana, natomiast amunicja ma być przechowywana w odpowiednich pudełkach lub pojemnikach.

5 Zob. Ł. Mikowski, Organy ochrony środowiska w systemie bezpieczeństwa społeczności lokalnych, [w:] Organ administracji publicznej w systemie bezpieczeństwa społeczności lokalnych, red. J. Boć, Ł. Mikowski, Wałbrzych 2016, s. 90.

6 Dz.U. z 2019 r. poz. 284 ze zm.

7 Dz.U. poz. 1224.

8 Osoby posiadające broń w celach kolekcjonerskich oraz pamiątkowych mogą ją przechowywać w przeszkolonych gablotach przeznaczonych do przechowywania broni po spełnieniu dodatkowych warunków wskazanych w $\S 6$ analizowanego rozporządzenia. 
Okoliczności uzasadniające powstanie odpowiedzialności z tytułu nienależytego zabezpieczenia broni palnej związane są także z regulacją zawartą w art. 35 komentowanej ustawy, w którym sformułowany został obowiązek zachowania niezbędnych środków bezpieczeństwa przy przewożeniu broni w środkach transportu publicznego. Dopuszczalne jest to pod warunkiem, że broń i amunicja są zabezpieczone w sposób uniemożliwiający powstanie zagrożenia życia, zdrowia lub mienia. Warto w tym miejscu wspomnieć, że przewoźnik może ustalić dodatkowe zasady przewozu broni w wewnętrznych regulaminach, przy których naruszeniu można narazić się na ustalony rodzaj odpowiedzialności. Postanowienia te zostały również wzmocnione przez określenie warunków noszenia broni zawarte w $\S 8$ rozporządzenia Ministra Spraw Wewnętrznych w sprawie przechowywania, noszenia oraz ewidencjonowania broni i amunicji. Noszenie broni palnej, także w środkach transportu publicznego ${ }^{9}$, wymaga daleko posuniętej dyskrecji, która przez spełnienie wymogu ochrony przed wzrokiem postronnych osób ma dodatkowo gwarantować subiektywne odczuwanie bezpieczeństwa osobistego ${ }^{10}$.

Kolejna sfera bezpieczeństwa związana z transportowaniem broni po terytorium kraju, której naruszenie może spowodować odpowiedzialność prawną, została zdeterminowana przepisami określającymi możliwość przesyłania broni i amunicji na odległość. Regulacja taka została zawarta w art. 36 komentowanej ustawy, w którym dopuszczone zostało przesyłanie broni i amunicji na terytorium kraju wyłącznie za pośrednictwem operatorów świadczących usługi pocztowe, pod warunkiem że mają one prawnie określone możliwości zagwarantowania bezpieczeństwa takim

${ }^{9}$ Wyłączeniu (szczególnym regulacjom) podlegają tu pasażerskie statki powietrzne, w których zgodnie z $§ 5$ rozporządzenia Ministrów Transportu i Gospodarki Morskiej oraz Spraw Wewnętrznych i Administracji z dnia 10 kwietnia 2000 roku w sprawie przewożenia broni i amunicji środkami transportu publicznego (Dz.U. Nr 31, poz. 390 ze zm.) broń może być przewożona wyłącznie w lukach bagażowych lub w miejscu wskazanym przez przewoźnika jako bagaż rejestrowany, do którego pasażerowie nie mają dostępu.

10 Do tego celu służą odpowiednie kabury zamocowane pod odzieniem wierzchnim w sposób przylegający do ciała oraz futerały czy specjalne walizki. Oczywiście inaczej jest w wypadku broni myśliwskiej, która ze względu na swoje przeznaczenie i budowę noszona jest $\mathrm{w}$ trakcie polowania w obwodach łowieckich w sposób określony odrębnymi przepisami. Zob. art. 43 ust. 3 ustawy z dnia 13 października 1995 roku — Prawo łowieckie (Dz.U. z 2013 r. poz. 1226 ze zm.). 
przesyłkom. Wymogi dla bezpiecznego przesyłania broni zostały określone w rozporządzeniu Ministra Spraw Wewnętrznych z dnia 24 sierpnia 2012 roku w sprawie szczegółowego trybu i warunków przesyłania broni lub amunicji za pośrednictwem operatorów świadczących usługi pocztowe ${ }^{11}$. Katalog wymogów zarówno prawnych, jak i technicznych, które muszą zostać spełnione przy przesyłaniu broni ${ }^{12}$, jednoznacznie wskazuje, że naraża się na odpowiedzialność prawną nie tylko ten, kto będąc zobowiązany ze względu na szczególny rodzaj działalności, jaką wykonuje, nie gwarantuje bezpieczeństwa broni w trakcie przesyłania, lecz także ten, kto przekazuje broń do przesłania podmiotowi nieświadczącemu takich usług. Tym samym należy wnioskować, że każde przekazanie broni palnej osobie trzeciej z dyspozycją przewiezienia jej od posiadacza broni do adresata należy traktować jako udostępnienie broni osobie nieupoważnionej, przez co wyczerpane zostają przesłanki odpowiedzialności prawnej w zakresie przesyłania broni i amunicji.

Swoistym przykładem wyczerpania przesłanki naruszającej obowiązek prawidłowego zabezpieczenia broni przed dostępem osób nieuprawnionych może być udostępnienie broni osobie trzeciej w drodze nieprawidłowo skonstruowanej czy wadliwie zinterpretowanej umowy użyczenia, która została przewidziana w art. 28 omawianej ustawy. $\mathrm{Z}$ analizy tego przepisu wynika, że jedynie broń do celów sportowych i łowieckich może zostać użyczana osobom posiadającym pozwolenie na broń do takich samych celów. Należy przy tym zauważyć, że naraża się na odpowiedzialność prawną zarówno ten, kto użycza, jak i bierze w użyczenie broń zarówno niewskazaną w tym przepisie (przeznaczoną do innych celów), jak i broń, która będzie przekraczała dozwoloną liczbę sztuk określoną w pozwoleniu na broń osoby biorącej w użyczenie.

11 Dz.U. poz. 1004.

12 Broń lub amunicję przesyła się w opakowaniu zaplombowanym i oznakowanym wraz z pouczeniem: „Znalazca niniejszej przesyłki powinien niezwłocznie przekazać ją najbliższej jednostce policji. Przesyłki nie rozplombowywać i nie otwierać”. Operator podczas przewożenia przesyłki zapewnia bezpośrednią ochronę fizyczną przesyłki przez pracownika ochrony uzbrojonego w broń palną bojową. Do przewożenia przesyłek używane są pojazdy spełniające wymagania dla pojazdów przewożących wartości pieniężne oraz pojazdów ubezpieczających, określone w przepisach wydanych na podstawie art. 6 ust. 2 ustawy z dnia 22 sierpnia 1997 roku o ochronie osób i mienia (Dz.U. z 2018 r. poz. 2142 ze zm.). 
Trzeba mieć także na uwadze możliwość szybkiego i sprawnego wykazania faktu zawarcia takiej umowy w czasie kontroli, albowiem umowa użyczenia nie wymaga dla swojej skuteczności formy pisemnej. O ile taki problem nie będzie dotyczył sportowców biorących udział w tych samych zawodach ${ }^{13}$, o tyle sytuacja, w której mamy do czynienia z użyczeniem broni osobie, która nie może takiego faktu potwierdzić bezpośrednio w czasie kontroli ${ }^{14}$, może być problematyczna. Za możliwością użyczenia takiej tylko broni przemawiają argumenty celowościowe, związane z korzystaniem z broni sportowej i myśliwskiej, które jednak bezwzględnie wykluczają zawarcie takiej umowy dla pozostałych rodzajów broni. Wyczerpanie przesłanek nieprawidłowego użyczenia broni będzie zatem miało miejsce zarówno w sytuacji, gdy rozminie się cel użyczenia, jak i zostanie przekroczona liczba sztuk broni określona w pozwoleniu na broń osoby biorącej w użyczenie. Nie wydaje się przy tym słuszny pogląd, że osoba użyczająca broń nie jest zobowiązana do sprawdzenia, czy biorący w użyczenie posiada pozwolenie na broń tej samej kategorii, przy czym użyczający broń niekoniecznie musi mieć wiedzę, jaką liczbę broni rzeczywiście już posiada biorący w użyczenie i czy w wyniku tej konkretnej umowy nie zostanie przekroczona liczba określona w jego pozwoleniu na broń ${ }^{15}$.

$\mathrm{Z}$ podobnymi okolicznościami, które wyczerpią przesłankę odpowiedzialności prawnej, związanymi z niezapewnieniem bezpieczeństwa fizycznego broni palnej w postaci umożliwienia wejścia w jej posiadanie osoby nieuprawnionej mamy do czynienia w wyniku porzucenia

13 Jest to dość częsta praktyka, spotykana szczególnie na zawodach klubowych, w których udział biorą nowi adepci strzelectwa sportowego, nieposiadający jeszcze własnej broni, ale legitymujący się pozwoleniem na broń danego rodzaju.

14 Użyczenie broni na czas polowania lub zawodów, w których nie biorą udziału obie strony umowy.

${ }^{15}$ W tym miejscu można postawić pytanie, czy strzelec sportowy lub myśliwy, który posiada zarejestrowaną na siebie jedną sztukę broni (zgodnie z decyzją, która przyznaje uprawnienie do posiadania jednej sztuki broni), biorąc w użyczenie broń na zawodach sportowych lub na polowaniu (jego broń znajduje się na przykład w naprawie u rusznikarza), przekracza prawne możliwości związane z umową użyczenia, czy nie? Tym samym, czy zostają wyczerpane przesłanki odpowiedzialności prawnej? Ze względu na liczne okoliczności wymagające wyjaśnienia, które nie stanowią trzonu rozważań przedmiotowych wywodów, odpowiedź na to pytanie będzie przedmiotem odrębnego dyskursu. 
broni palnej lub amunicji. Odpowiedzialność taka została przewidziana w art. 50 analizowanej ustawy. Porzucenie broni należy jednak odróżnić od zgubienia broni. W tym wypadku mamy bowiem do czynienia z działaniem celowym i świadomym. Porzucenie broni negatywnie wpływa na bezpieczeństwo porządku publicznego, mimo że w takim przypadku nie ma osoby bezpośrednio pokrzywdzonej. Z uwagi na to, że posiadać broń palną można wyłącznie na podstawie pozwolenia na broń, przesłanki odpowiedzialności prawnej w momencie porzucenia broni mogą zostać wyczerpane jedynie przez osobę legalnie posiadającą broń — „Nie może być sprawcą tego przestępstwa osoba, która porzuciła nielegalnie posiadaną broń"16.

\section{Obowiązek informacyjny i rejestracyjny}

Szczególną, zbiorczą kategorią obowiązków, których naruszenie naraża posiadacza broni na odpowiedzialność prawną, jest szeroko rozumiany obowiązek informacyjny. Ustawodawca w art. 13 ustawy o broni i amunicji nakłada bowiem obowiązek zarejestrowania broni w terminie pięciu dni od jej nabycia. Rejestracji broni, w drodze czynności materialno-technicznej ${ }^{17}$, dokonuje na podstawie dowodu nabycia komendant

16 S. Maj, Ustawa o broni i amunicji. Komentarz, Warszawa 2010. Nie tracąc z pola widzenia głównego celu penalizowania takiego zachowania, należy rozważyć sytuację, w której znalazca broni nie zgłasza takiego faktu właściwym organom (zob. przepisy dotyczące rzeczy znalezionych: art. 180-183 ustawy z dnia 23 kwietnia 1964 roku Kodeks cywilny, Dz.U. z 2019 r. poz. 1145 ze zm.), obejmuje w posiadanie broń palną, po czym po pewnym czasie ją porzuca. Czy w takim przypadku, oprócz niewykonania obowiązku informacyjnego, nie powoduje okoliczności, które legły u podstaw sankcjonowania porzucenia broni?

17 Czynności o charakterze materialno-technicznym wywołują skutki prawne w sposób właściwy dla działań organów administracyjnych związanych z dokonywaniem pewnych czynności mających walor ustaleń faktycznych; zob. A. Błaś, Prawne formy działania administracji publicznej, [w:] Prawo administracyjne, red. J. Boć, Wrocław 2010, s. 349. Z zapisu literalnego art. 13 ust. 1 komentowanej ustawy może wynikać, że taka czynność materialno-techniczna jest naturalną konsekwencją nabycia broni na podstawie wcześniej wydanej decyzji administracyjnej przez właściwy organ i stanowi wyłącznie formalność. Pominąć należy sytuacje, gdy do rejestracji przedstawiona zostanie broń, która wykracza poza ramy jednoznacznie określone w pozwoleniu na broń; zob. R. Mikowski, Kilka uwag o prawnych formach działania administracji $w$ zakresie 
wojewódzki policji. Potwierdzeniem rejestracji broni jest odpowiedni wpis w legitymacji posiadacza broni, podczas gdy nabycie broni palnej następuje na podstawie zaświadczenia wydanego na wniosek osoby posiadającej pozwolenie na broń, w którym zostaje określony rodzaj i liczba egzemplarzy broni zgodnie z pozwoleniem. Takie zaświadczenie (promesa) stanowi swego rodzaju dokument rozliczeniowy (ewidencjonujący obieg broni) między nabywcą, sprzedawcą a organem wydającym pozwolenie na broń. Niezrealizowanie obowiązku rejestracji broni lub przekroczenie pięciodniowego terminu jest przesłanką odpowiedzialności prawnej. Dla organu nie ma tu znaczenia, czy mieliśmy do czynienia z całkowitym zaniechaniem dokonania wymaganej czynności, czy tylko z nieznacznym przekroczeniem ustawowego terminu, co wydaje się szczególnie dotkliwe, gdy przyjdzie starać się w przyszłości o wydanie takiego uprawnienia na kolejne sztuki broni.

Zapewnienie bezpieczeństwa fizycznego broni przez jej posiadacza polega także na informowaniu właściwego organu policji o każdej zmianie związanej z realnym posiadaniem broni. Zgodnie z art. 25 analizowanej ustawy posiadacz broni zobowiązany jest zawiadomić ${ }^{18}$ o utracie broni właściwy organ w nieprzekraczalnym terminie 24 godzin od momentu stwierdzenia jej braku. Ustawodawca, widząc w takiej okoliczności szczególne zagrożenie dla bezpieczeństwa, kładzie nacisk na niezwłoczne powiadomienie policji lub żandarmerii wojskowej. Podobnie — ze względu na wymóg ewidencjonowania obrotu bronią — ustawodawca traktuje zbycie broni i amunicji pomiędzy osobami posiadającymi pozwolenie na ten sam rodzaj broni. Dopuszczając taką możliwość, nakłada jednocześnie w art. 21 ust. 2 ustawy o broni i amunicji obowiązek niezwłocznego i pisemnego powiadomienia o takim fakcie właściwego organu policji. Należy zauważyć, że te dwie okoliczności wpływające na zmianę fizycznego

dostęu do broni palnej, [w:] Administracja publiczna pod rzadami prawa. Księga pamiątkowa z okazji 70-lecia urodzin prof. zw. dra hab. Adama Błasia, red. J. Korczak, Wrocław 2016, s. 343.

${ }^{18} \mathrm{~W}$ sytuacji utraty broni posiadacz staje przed dylematem wyczerpania przesłanek odpowiedzialności prawnej za utratę broni czy za niepoinformowanie organu o tym fakcie. W jednym i drugim wypadku przewidziana została sankcja; szerzej zob. R. Rejmaniak, Obowiazek zawiadomienia o utracie broni palnej, „Prokuratura i Prawo” 2017, nr 5, s. 13-36. 
posiadania nie są traktowane przez ustawodawcę jednakowo. W związku ze świadomym, kontrolowanym przeniesieniem własności (i posiadania) broni w drodze umowy kupna-sprzedaży czy też umowy darowizny obowiązek informacyjny sprowadza się do niezwłocznego ${ }^{19}$ informowania. Ustawodawca nie widzi tutaj aż takiego niebezpieczeństwa jak w wypadku nieświadomej utraty posiadania broni, co dodatkowo jest niwelowane przez obowiązek nabywcy broni do zarejestrowania broni w terminie pięciu dni. Chociaż rejestracja broni nie zwalnia zbywcy z poinformowania o takim fakcie właściwego organu, to jednak w pewien sposób ewidencjonuje (potwierdza) zmianę faktycznego posiadania broni, czego nie można powiedzieć o sytuacji zagubienia broni.

Do obowiązku informacyjnego należy zaliczyć także zawiadomienie o zmianie miejsca stałego pobytu. W tym wypadku, zgodnie z art. 26 komentowanej ustawy, osoba posiadająca pozwolenie na broń jest obowiązana zawiadomić o tym pisemnie organ policji właściwy ze względu na nowe miejsce stałego pobytu w terminie 14 dni od dnia zmiany miejsca stałego pobytu. Z uwagi na to, że właściwy organ policji kompetentny jest do przeprowadzania kontroli sposobu przechowywania broni w miejscu wskazanym przez posiadacza broni ${ }^{20}$, niepoinformowanie o zmianie takiego miejsca stanowi istotne utrudnienie w przeprowadzeniu odpowiednich czynności, a co za tym idzie negatywnie wpływa również na bezpieczeństwo fizyczne broni palnej.

\section{Noszenie broni oraz środki odurzające}

Negatywnie na posiadane uprawnienie wpływa także pozostawanie pod wpływem alkoholu, środka odurzającego lub substancji psychotro-

19 Określenie to nie należy do terminów ostrych i wydaje się, że celowo nie zostało w tym miejscu dookreślone przez ustawodawcę, jak ma to miejsce w wypadku zgubienia broni.

${ }^{20}$ Miejsce stałego pobytu nie musi być miejscem przechowywania broni, ale w praktyce najczęściej nim jest, jeżeli mówimy o osobach posiadających broń na podstawie pozwolenie na broń. Wyjątek mogą tutaj stanowić przypadki związane na przykład z wykonywaniem pracy w firmach ochroniarskich, w wypadku których mamy do czynienia $\mathrm{z}$ tak zwaną bronią obiektową, którą pobiera się i zdaje w ochranianym obiekcie lub na czas wykonywania czynności zawodowych. 
powej albo środka zastępczego w czasie „kontaktu z bronią”. Konkretnie ustawodawca neguje tutaj możliwość przemieszczania się pod wpływem takich środków nawet $\mathrm{z}$ rozładowaną bronią. Broń i alkohol nigdy bowiem nie idą w parze, czemu ustawodawca daje wyraz już przy staraniu się przez wnioskodawcę o wydanie pozwolenia na broń, uzależniając wydanie decyzji pozytywnej od niewystępowania u niego takich uzależnień. Chociaż przepis art. 18 ust. 1 pkt 4 nie wskazuje jednoznacznie przestrzeni, po której nie można się poruszać z bronią pod wpływem alkoholu, to jednak uprawniony wydaje się wniosek, że dotyczy to zarówno przestrzeni publicznej, jak i „domowych zaciszy”. Naruszenie „zasady trzeźwości" w każdym przypadku obligatoryjnie powoduje odpowiedzialność prawną posiadacza broni. Wojewódzki Sąd Administracyjny w Warszawie w wyroku z dnia 29 lipca 2010 roku $^{21}$ podkreślił, że powinny być bezwzględnie eliminowane zachowania osób posiadających pozwolenie na broń palną polegające na noszeniu broni pod wpływem alkoholu czy też innego środka odurzającego. Osoby w takim stanie, mając zaburzoną zdolność oceny swojego zachowania, mogą wszak stracić umiejętność racjonalnego kierowania swoim działaniem. Zdaniem sądu nie ma przy tym znaczenia, jakie okoliczności doprowadziły do przemieszczania się z bronią osoby po użyciu alkoholu ani też, na jaką broń ma ona pozwolenie.

Nieprawidłowości związane z noszeniem broni, oprócz stanów świadomości związanych ze środkami odurzającymi, mogą mieć miejsce także w wypadku noszenia broni w sytuacji ograniczeń zawartych w legitymacji posiadacza broni czy też wynikających z czasowych zakazów noszenia broni na określonym terenie, wprowadzonych przez właściwy organ. Decyzja z pozwoleniem na broń, dając uprawnienie do legalnego posiadania broni, zawiera $\mathrm{w}$ sobie tym samym prawo transportowania tej broni oraz prawo noszenia broni, oczywiście przy zachowaniu odpowiednich wymogów związanych z jej bezpieczeństwem. Ustawodawca wskazuje wyraźnie zakaz noszenia jedynie broni kolekcjonerskiej i pamiątkowej, który wprost wynika z art. 10 ust. 8 analizowanej ustawy. $\mathrm{Z}$ literalnego brzmienia tego przepisu można wnioskować, że zakaz ten może zostać złagodzony przez wydanie specjalnej zgody na noszenie

${ }^{21}$ Sygn. II SA/Wa 706/09, LEX nr 69447. 
tego typu broni. Tym samym na noszenie pozostałych rodzajów broni taka zgoda nie jest wymagana, aczkolwiek taki zakaz może zostać wprowadzony i oznaczony w legitymacji posiadacza broni, przy czym nie jest jasne, w jakich sytuacjach i jakimi kryteriami ${ }^{22}$ organ będzie się kierował. Ograniczenia związane z noszeniem broni palnej mogą wynikać także z czasowych zakazów wprowadzonych przez właściwego ministra. Zgodnie z art. 33 analizowanej ustawy minister właściwy do spraw wewnętrznych może wprowadzić taki zakaz ze względu na ochronę interesu państwa lub porządku publicznego. Rozporządzenie ministra może obejmować terytorium całego państwa lub jego określony obszar, przy czym może dotyczyć wszelkich lub tylko niektórych rodzajów broni. Zakaz noszenia lub przemieszczania się z bronią zawarty w regulacjach rozporządzeniowych tyczy się z reguły ograniczonego terytorium, na którym organizowane są imprezy okolicznościowe, sportowe czy wizyty VIP-ów. Takie okoliczności uzasadniające ograniczenia związane z posiadaniem broni palnej na podstawie uprzednio wydanej ostatecznej decyzji administracyjnej zostały dotychczas uwzględnione 16 razy (trzy ostatnie miały miejsce w 2019 roku $^{23}$ ).

Pozwolenie na broń, jako decyzja administracyjna, daje uprawnienia między innymi do noszenia broni w sposób ściśle określony przepisami

22 Wydaje się, że uznaniowość działania organu w zakresie ograniczania prawa do noszenia legalnie posiadanej broni nie jest pożądana; wykonanie bowiem tego prawa, opierając się na luzie decyzyjnym, może prowadzić do obiektywnych naruszeń. Szerzej na temat granic swobodnego uznania zob. J. Zimmermann, Prawo administracyjne, Warszawa 2014, s. 310-311.

23 Zob. m.in. rozporządzenie Ministra Spraw Wewnętrznych i Administracji z dnia 22 lipca 2019 roku w sprawie wprowadzenia czasowego zakazu noszenia broni i przemieszczania jej w stanie rozładowanym (Dz.U. poz. 1377) ze względu na Pol'and'Rock Festival organizowany w dniach 1-3 sierpnia 2019 roku na obszarze gminy Kostrzyn nad Odrą i sołectwa Dąbroszyn w gminie Witnica w województwie lubuskim oraz rozporządzenie Ministra Spraw Wewnętrznych i Administracji z dnia 5 lutego 2019 roku w sprawie wprowadzenia czasowego zakazu noszenia broni i przemieszczania jej w stanie rozładowanym (Dz.U. poz. 233) w związku z organizowanym w dniach 13-14 lutego 2019 roku na terenie miasta stołecznego Warszawy spotkania ministerialnego poświęconego budowaniu pokoju i bezpieczeństwa na Bliskim Wschodzie. Powodem wprowadzenia tego typu zakazów były w szczególności organizacja 41. Sesji Komitetu Światowego Dziedzictwa UNESCO w Krakowie, wizyta w Polsce prezydenta Donalda Trumpa czy zawody The World Games 2017 organizowane we Wrocławiu. 
prawa. Dokumentem potwierdzającym posiadanie takiego uprawnienia jest legitymacja posiadacza broni ${ }^{24}$, która oprócz elementów identyfikujących posiadacza broni oraz cech samej broni może zawierać dodatkowe wpisy, na przykład o wyłączeniu lub ograniczeniu możliwości noszenia broni, o których mowa w art. 10 ust. 7 ustawy o broni i amunicji. Na podstawie posiadania takiej legitymacji właściwe służby w trakcie kontroli są w stanie ustalić, czy noszenie danej broni nie jest czasowo wyłączone, ewentualnie nie jest generalnie wyłączone z mocy ustawy, jak ma to miejsce w wypadku broni posiadanej na podstawie pozwolenia do celów kolekcjonerskich lub pamiątkowych. Tym samym brak legitymacji posiadacza broni w razie kontroli może pociągnąc za sobą przewidzianą odpowiedzialność prawną.

\section{Cel posiadania i warunki użycia broni}

Decyzja z pozwoleniem na broń nadaje uprawnienie do legalnego zakupu i posługiwania się bronią palną. Zgodnie z art. 12 ust. 1 ustawy o broni i amunicji w decyzji administracyjnej określony zostaje cel, w jakim broń będzie używana, oraz rodzaj i liczba egzemplarzy broni. Stosownie do indywidualnych, ważnych powodów posiadania broni ustawodawca wyraźnie sprecyzował cel używania broni w art. 10 ust. 2 komentowanej ustawy, przez co wyłączył możliwość swobodnego interpretowania okoliczności powodujących powstanie odpowiedzialności prawnej. Wydaje się jednak, że posiadanie broni do celów ochrony osobistej oraz ochrony osób i mienia nie spowoduje odpowiedzialności prawnej w sytuacji treningu strzeleckiego na strzelnicy. Niestety odwrotne wnioskowanie nie jest już takie oczywiste, ponieważ zawężony zakres celowościowy używania na przykład broni sportowej w żadnej mierze nie uzasadnia użycia jej do innego celu niż określony w pozwoleniu. Tak samo wykorzystanie broni myśliwskiej do innych czynności niż związanych z uczestnictwem

24 Odpowiednio może to być, zgodnie z art. 7a ustawy o broni i amunicji, Europejska karta broni palnej, która jest imiennym dokumentem potwierdzającym uprawnienie do posiadania broni palnej, wydanym przez właściwy organ państwa członkowskiego Unii Europejskiej, umożliwiającym legalne posiadanie i używanie broni palnej w innym państwie członkowskim UE. 
w polowaniu niewątpliwie spowoduje odpowiedzialność prawną ${ }^{25}$. Cel używania broni określony w pozwoleniu na broń determinuje także rodzaj posiadanej broni, który został wskazany w art. 10 ust. 4 pkt $1-7^{26}$ ustawy o broni i amunicji. Ustawodawca, wyliczając w art. 10 ust. 3 analizowanej ustawy ważne przyczyny posiadania broni, akcentuje sytuacje, w których konkretny rodzaj broni może zostać użyty. Należy przy tym pamiętać, że zgodnie z art. 9 ust. 1 przedmiotowej regulacji pozwolenie na broń wymagane jest także do legalnego posiadania amunicji do broni określonej w pozwoleniu na broń. Tym samym cel posiadania broni palnej, wzmocniony przez określenie ważnych powodów posiadania danej kategorii broni, determinuje możliwość legalnego nabycia amunicji do tej broni. Mając powyższe na uwadze, trzeba podkreślić, że naraża się na odpowiedzialność prawną zarówno ten, kto posiada amunicję ${ }^{27}$ do broni niewskazanej w pozwoleniu na broń, jak i ten, kto posiada amunicję do broni pamiątkowej ${ }^{28}$. W wypadku broni pamiątkowej jasno i konkretnie sformułowane ważne powody jej posiadania ${ }^{29}$ nie uzasadniają strzelania $\mathrm{z}$ takiej broni w żadnych warunkach.

Podobnie skutkuje naruszenie zasady używania broni na strzelnicach, sformułowanej w art. 45 ustawy o broni i amunicji. Użycie broni palnej wykorzystywanej w celach szkoleniowych i sportowych poza strzelnicami stanowi ewidentne przekroczenie uprawnień wynikających z decyzji pozwolenia na broń. Przesłanki odpowiedzialności w takich sytuacjach zostały zdeterminowane przez cel używania broni, który został

${ }^{25}$ Należy pamiętać o sytuacjach szczególnych, związanych na przykład ze stanem wyższej konieczności czy z obroną konieczną, które za każdym razem są jednak oceniane indywidualnie i nie stanowią w tym opracowaniu głównego nurtu rozważań.

${ }^{26}$ Regulacja ta dopuszcza posiadanie broni o kalibrze do $12 \mathrm{~mm}$, przy czym należy zaznaczyć, że niedozwolone jest posiadanie broni szczególnie niebezpiecznej wskazanej w art. 10 ust. 5 pkt $1-4$.

${ }^{27}$ Ustawodawca w art. 10 ust. 6 kategorycznie wyłączył możliwość posiadania w każdym wypadku amunicji szczególnie niebezpiecznej, dając przy tym jasne wytyczne, co należy rozumieć pod tym pojęciem.

${ }^{28} \mathrm{~W}$ tym wypadku ustawodawca nie przewidział możliwości nabycia amunicji. Osoba posiadająca pozwolenie na broń do celów pamiątkowych nie zdaje egzaminu praktycznego z zasad działania i używania broni, przez co wątpliwe są jej umiejętności związane z obsługą broni palnej; zob. S. Maj, op. cit.

${ }^{29} \mathrm{~W}$ wypadku broni pamiątkowej - udokumentowane nabycie broni w drodze spadku, darowizny lub wyróżnienia. 
jasno oznaczony w decyzji administracyjnej oraz potwierdzony (również w sposób wizualny ${ }^{30}$ ) w legitymacji posiadacza broni. Należy przy tym zauważyć, że przepis ten nie determinuje warunków używania broni do celów ochrony osobistej lub ochrony osób i mienia oraz broni łowieckiej. W pierwszym wypadku używanie takiej broni nie jest ograniczone terytorialnie $^{31}$, przez co możliwe jest używanie jej także na strzelnicach, w drugim - ograniczenie nie dotyczy miejsca i czasu wykonywania polowania oraz, co wydaje się uzasadnione podnoszeniem umiejętności strzeleckich, strzelnic przeznaczonych dla członków Polskiego Związku Łowieckiego. Tak więc wyraźnie widać, że najbardziej zawężony został zakres użycia broni sportowej, zdeterminowany zarówno prawnie określonym celem jej posiadania, jak i wskazaniami zawartymi w art. 45 komentowanej ustawy.

Używanie broni palnej na strzelnicach zostało doprecyzowane w rozporządzeniu Ministra Spraw Wewnętrznych i Administracji z dnia 15 marca 2000 roku w sprawie wzorcowego regulaminu strzelnic ${ }^{32}$, w którym określono między innymi warunki korzystania ze strzelnicy, sposoby obchodzenia się z bronią i sposób zachowania się osób przebywających na strzelnicy. Co warte podkreślenia, na strzelnicy kategorycznie zabroniono osobom nieuprawnionym wchodzenia na stanowiska strzeleckie oraz styczności z bronią, a przede wszystkim przebywania na strzelnicy osób pod wpływem alkoholu lub środków odurzających, przy czym zakaz ten dotyczy wszystkich przebywających na strzelnicy bez wyjątku, zarówno pracowników strzelnicy, osób strzelających, jak i osób towarzyszących. Tym samym zakaz ten dotyczy także publiczności w trakcie trwania zawodów sportowych, co jednocześnie wyklucza świętowanie zwycięstwa alkoholem wszystkich przebywających na terenie strzelnicy.

30 Zob. wzór legitymacji posiadacza broni określony w rozporządzeniu Ministra Spraw Wewnętrznych z dnia 21 marca 2013 roku w sprawie wzorów legitymacji posiadacza broni, zaświadczenia uprawniającego do nabycia broni, legitymacji osoby dopuszczonej do posiadania broni, świadectwa broni oraz karty rejestracyjnej broni (Dz.U. z 2017 r. poz. 1612). W czwartej kolumnie organ wpisuje cel posiadania broni, który oznaczony jest odpowiednio dużymi, drukowanymi literami w kolejności oznaczonej na przedostatniej stronie książeczki.

31 Poza przypadkami związanymi z tak zwaną bronią obiektową.

32 Dz.U. Nr 18, poz. 234 ze zm. 


\section{Zmiana stanu zdrowia i ustanie okoliczności faktycznych}

Ustanie okoliczności faktycznych, które stanowiły podstawę wydania pozwolenia na broń, także pociąga za sobą skutki prawne dla posiadacza broni. Zgodnie z art. 10 ust. 3 pkt 1-7 okoliczności rozumiane jako ważne przyczyny uzasadniające wydanie pozwolenia na broń to w szczególności stałe, realne i ponadprzeciętne zagrożenie życia, zdrowia lub mienia ${ }^{33}$, posiadanie uprawnień do przeprowadzania polowania $^{34}$, udokumentowane członkostwo w stowarzyszeniu o charakterze strzeleckim ${ }^{35}$, udokumentowane członkostwo w stowarzyszeniu, którego statutowym celem jest organizowanie rekonstrukcji historycznych ${ }^{36}$, udokumentowane członkostwo w stowarzyszeniu o charakterze kolekcjonerskim ${ }^{37}$, udokumentowane nabycie broni w drodze spadku, darowizny lub wyróżnienia ${ }^{38}$ oraz posiadanie uprawnień, określonych w odrębnych przepisach, do prowadzenia szkoleń o charakterze strzeleckim, a także udokumentowane zarejestrowanie działalności gospodarczej w zakresie szkoleń strzeleckich ${ }^{39}$.

W pierwszej kategorii broni, oznaczonej literą A, wystarczy, że ustanie tylko jedna z trzech przesłanek, które muszą być spełnione łącznie, aby można było mówić o wszczęciu procedury skutkującej cofnięciem pozwolenia na broń. Podobnie, gdy osoba posiadająca pozwolenie na broń kategorii B przestanie wykonywać czynności zawodowe związane $\mathrm{z}$ ochroną osób lub mienia. Również wykluczenie z członkostwa w PZŁ czy PZSS lub innym stowarzyszeniu o charakterze strzeleckim będzie determinowało powstanie odpowiedzialności prawnej wynikającej z pozwolenia na broń palną. Co warte podkreślenia, strzelcy sportowi do utrzymania licencji sportowej, a tym samym pozwolenia na broń, zobowiązani są do określonej liczby startów w czasie roku kalendarzowego w konkurencjach strzeleckich wyszczególnionych w kalendarzu PZSS.

${ }^{33}$ Pozwolenie na broń do celów ochrony osobistej (A), do celów ochrony osób i mienia (B).

${ }^{34}$ Pozwolenie na broń do celów łowieckich (C).

${ }^{35}$ Pozwolenie na broń do celów sportowych (D).

${ }^{36}$ Pozwolenie na broń do celów rekonstrukcji historycznych (R).

${ }^{37}$ Pozwolenie na broń do celów kolekcjonerskich (E).

38 Pozwolenie na broń do celów pamiątkowych $(\mathrm{G})$.

${ }^{39}$ Pozwolenie na broń do celów szkoleniowych $(\mathrm{H})$. 
Niespełnienie takiego wymogu mimo członkostwa w klubie uzasadnia odmowę przedłużenia licencji sportowej, co może być poczytywane za ustanie przesłanki istnienia ważnej przyczyny posiadania broni palnej do celów sportowych ${ }^{40}$.

Z uwagi na to, że jedną z przesłanek wydania pozwolenia na broń jest wykazanie niestwarzania zagrożenia dla samego siebie, okoliczność ta $\mathrm{w}$ razie zmiany na niekorzyść osoby posiadającej uprawnienie powoduje automatyczną odpowiedzialność prawną skutkującą cofnięciem pozwolenia na broń. Za taką okoliczność należy uznać wystąpienie zaburzeń psychicznych, o których mowa w ustawie z dnia 19 sierpnia 1994 roku o ochronie zdrowia psychicznego ${ }^{41}$, lub znacznego ograniczenia sprawności psychofizycznej. Istotne zaburzenia funkcjonowania psychologicznego oraz uzależnienie od alkoholu lub substancji psychoaktywnych także będą postrzegane jako okoliczność o negatywnym wpływie na dotychczasową sytuację prawną posiadacza broni. Tej samej odpowiedzialności prawnej podlegać będzie osoba, która wyczerpie przesłanki określone w art. 15 ust. 1 pkt 6 komentowanej ustawy. Skazanie prawomocnym orzeczeniem sądu za umyślne przestępstwo lub umyślne przestępstwo skarbowe czy też za nieumyślne przestępstwo przeciwko życiu i zdrowiu, ale i przeciwko bezpieczeństwu w komunikacji popełnione w stanie nietrzeźwości lub pod wpływem środka odurzającego potraktowane zostanie jako stworzenie zagrożenia dla porządku lub bezpieczeństwa publicznego.

Kontestując przepisy formułujące zasadę dostępu do broni palnej wyłącznie w szczególnych okolicznościach, po spełnieniu restrykcyjnych wymogów, można bez problemu zauważyć zamierzenia racjonalnego ustawodawcy, aby nie dopuścić do sytuacji, w których taki dostęp otrzymają osoby wykazujące się jawną nieodpowiedzialnością i nieposzanowaniem prawa. W taki właśnie sposób należy oceniać każdego, kto w stanie nietrzeźwości porusza się po drodze publicznej ${ }^{42}$.

40 Nie można uprawiać sportu poprzez bezczynność — bierną postawę.

41 Dz.U. z 2018 r. poz. 1878.

42 Zob. wyrok Wojewódzkiego Sądu Administracyjnego w Warszawie z dnia 5 grudnia 2012 roku, sygn. II SA/Wa 1763/12, LEX nr 1413133. 


\section{Podsumowanie}

W celu zagwarantowania poczucia bezpieczeństwa ${ }^{43}$ ustawodawca nakłada na posiadacza broni wiele obowiązków, których niedochowanie, jak też przekroczenie uprawnień wynikających z samej decyzji administracyjnej, uruchomi nie tylko administracyjne, lecz także karne procedury prowadzące do przewidzianej w przepisach prawa odpowiedzialności. Wyczerpanie okoliczności związanych z przekroczeniem uprawnień wynikających z pozwolenia na broń skutkuje, zgodnie z art. 18 ustawy o broni i amunicji, sankcją administracyjną $\mathrm{w}$ postaci obligatoryjnego cofnięcia pozwolenia na broń $^{44}$. Kategoryczne stwierdzenie ,właściwy organ policji cofa pozwolenie na broń" świadczy o braku jakiejkolwiek swobody w posługiwaniu się przez organ sądami wartościującymi w tym zakresie i wskazuje na konieczność wydania decyzji ${ }^{45}$ administracyjnej związanej. Wyczerpanie tak sformułowanych przesłanek cofnięcia pozwolenia na broń oznacza czysto wykonawczy charakter działania organu, zdeterminowany wyczerpującą

43 Należy odróżnić odczuwanie bezpieczeństwa przez jednostkę od prawnych założeń państwa, związanych z realnym stanem określanym mianem bezpieczeństwa. Można w tym miejscu wskazać nie tylko na regulacje prawne w różnych państwach Unii Europejskiej i na świecie, lecz przede wszystkim na zwyczaje i tradycje związane $\mathrm{z}$ posiadaniem broni palnej w danym miejscu. Kwestia bezpiecznego przewożenia broni w środkach komunikacji miejskiej zgoła odmiennie uregulowana jest bowiem w rodzimym ustawodawstwie, a inaczej na przykład w Szwajcarii, gdzie właśnie ze względu na odczuwanie bezpieczeństwa przez jednostkę należy broń przewozić w sposób widoczny. W Polsce człowiek z bronią w tramwaju raczej nie wpłynie pozytywnie na subiektywne odczuwanie bezpieczeństwa przez współpasażerów.

${ }^{44} \mathrm{Z}$ takim rodzajem reakcji właściwego organu policji będziemy mieli do czynienia, gdy posiadacz broni nosi broń pomimo ograniczenia lub wykluczenia możliwości jej noszenia. Podobna sankcja dotknie tego, kto wykazuje zaburzenia psychiczne, znaczne ograniczenia sprawności psychofizycznej, istotne zaburzenia funkcjonowania psychologicznego. Podstawą do cofnięcia pozwolenia na broń będzie także uzależnienie od alkoholu lub substancji psychoaktywnych, noszenie lub przemieszczanie broni pod wpływem alkoholu czy brak miejsca stałego pobytu na terytorium Rzeczypospolitej Polskiej. Organ obligatoryjnie cofa pozwolenia na broń osobie, która stanowi zagrożenie dla siebie, porządku lub bezpieczeństwa publicznego albo nie dopełnia obowiązku zawiadomienia o utracie broni.

45 Zgodnie z art. 20 komentowanej ustawy cofnięcie pozwolenia na broń następuje $\mathrm{w}$ drodze decyzji administracyjnej. 
regulacją ${ }^{46}$. Ustawodawca przewidział również możliwość fakultatywnego $^{47}$ cofnięcia pozwolenia na broń, pozostawiając organowi w tym zakresie pewien zakres swobody co do oceny rozmiaru naruszenia przepisów, a w szczególności skutków i oddziaływania na sferę bezpieczeństwa obywateli. W sytuacjach zagrożenia bezpieczeństwa publicznego, w tym związanych z cofnięciem pozwolenia na broń, ustawodawca przewidział możliwość odebrania broni i amunicji za pokwitowaniem. Taka czynność administracyjno-porządkowa wynika z zapisu art. 19 ustawy o broni i amunicji, co dodatkowo zostało wzmocnione przez przekazanie broni do depo$z_{t u}{ }^{48}$. Sankcje związane z wyczerpaniem przesłanek odpowiedzialności za naruszenie uregulowań związanych z pozwoleniem na broń palną mogą mieć nie tylko skutki doraźne, ale też mogą rzutować na przyszłą sytuację prawną osoby dopuszczającej się takiego naruszenia. W art. 17 komentowanej ustawy przewidziana została możliwość odmowy wydania w przyszłości pozwolenia na broń osobie, która już takie pozwolenie ma.

Szczególnie niebezpieczne naruszenia obowiązków związanych z posiadanym pozwoleniem na broń są dodatkowo sankcjonowane w rozdziale $5^{49}$ ustawy o broni i amunicji. W art. 50 analizowanego rozdziału prze-

46 Dlatego też tego typu prawne formy działania organów zaliczane są do działań o charakterze czysto wykonawczym. Podejmowane są na podstawie wyraźnych przepisów prawa, co determinuje działanie organu od początku do końca przez normy ustrojowe, materialne i proceduralne; zob. Prawo administracyjne, red. J. Boć, s. 360; por. E. Ura, S. Pieprzny, Postepowanie $w$ sprawach wydawania pozwoleń na broń palna, [w:] Kodyfikacja postepowania administracyjnego na 50-lecie K.P.A., red. J. Niczyporuk, Lublin 2010, s. 859.

47 Jeżeli ustały okoliczności faktyczne, które stanowiły podstawę do jego wydania, naruszenia przez osobę posiadającą pozwolenie obowiązku rejestracji broni, obowiązku poddania się badaniom lekarskim i psychologicznym i przedstawienia orzeczeń lekarskiego i psychologicznego, obowiązku zawiadomienia właściwego organu policji o zmianie miejsca stałego pobytu, zasad przechowywania, noszenia oraz ewidencjonowania broni i amunicji, wymogu uzyskania zgody na wywóz broni i amunicji za granicę, użycia broni sportowej poza strzelnicą czy zakazu użyczania broni osobie nieupoważnionej.

48 Zob. rozporządzenie Ministra Spraw Wewnętrznych i Administracji z dnia 9 czerwca 2004 roku w sprawie szczegółowych zasad deponowania i niszczenia broni i amunicji w depozycie Policji, Żandarmerii Wojskowej lub organu celnego oraz stawki odpłatności za ich przechowywanie w depozycie (Dz.U. Nr 152, poz. 1609).

49 Zbieżne uregulowania można odnaleźć w art. 263 § 3-4 ustawy z dnia 6 czerwca 1997 roku — Kodeks karny (Dz.U. z 2019 r. poz. 1950), przy czym w komentowanym zakresie dotyczą one tutaj każdego posiadacza broni palnej i amunicji; zob. R. Rejma- 
widziane zostały grzywna i kara ograniczenia wolności albo pozbawienia wolności do lat dwóch. Podobnie penalizowane są zachowania w art. 51 ustawy o broni i amunicji, w którym za naruszenia przepisów będące wykroczeniami ${ }^{50}$ przewidziano karę aresztu bądź grzywny. Z uwagi na szczególny rodzaj ochrony, związany z bezpieczeństwem publicznym w ramach regulacji dotyczących broni palnej, gwarancje efektywności takich rozwiązań prawnych zostały wzmocnione w art. 51 ust. 4 przedmiotowej regulacji poprzez możliwość orzekania przepadku broni i amunicji, co ze względu na niejednokrotnie znaczną wartość przedmiotów niewątpliwie jest dodatkową dotkliwością ekonomicznego wymiaru penalizowania wskazanych naruszeń.

Konkludując, należy stwierdzić, że katalog naruszeń związanych z okolicznościami wpływającymi na bezpieczeństwo broni palnej, pomimo swojej różnorodności, stanowi zbiór zamknięty. Przesłanki powodujące zastosowanie karnoprawnych instrumentów zawsze implikują władczą reakcję państwa ${ }^{51}$, właściwą dla administracyjnoprawnej metody regulacji. Jak można zauważyć z przytoczonego zestawienia, nie każda sankcja administracyjnoprawna jest związana z okolicznościami, które są niepożądane z punktu widzenia prawa karnego. Administracyjnoprawne sankcjonowanie w tym zakresie nie wyklucza stosowania innych form karania $^{52}$, ponieważ — jak twierdzi Janusz Malanowski ${ }^{53}$ — administra-

niak, Obowiąek zawiadomienia..., s. 13-36; A. Muller, Przestępstwo porzucenia broni palnej i amunicji, „Wojskowy Przegląd Prawniczy” 2017, nr 3, s. 71-77.

50 „Dla bytu wykroczenia wystarczy, aby sprawca wypełnił znamiona chociażby jednego z wymienionych sposobów zachowania się" - W. Kotowski, B. Kurzępa, Komentarz do niektórych przepisów ustawy o broni i amunicji, [w:] eidem, Wykroczenia pozakodeksowe. Komentarz, wyd. 2, Warszawa 2008, LEX, komentarz do art. 51.

${ }^{51}$ Nie należy postrzegać cofnięcia pozwolenia na broń jako kary dodatkowej wobec kary orzeczonej w takich okolicznościach przez sąd karny za popełnione przestępstwo, tym samym nie można jej traktować jako powtórnego karania za ten sam czyn; zob. M. Rogalski, Odpowiedzialność karna a odpowiedzialność administracyjna, „Ius Novum" 2014, nr 1, s. 66-80.

52 M. Stahl, Sankcje administracyjne - problemy węzłowe, [w:] Sankcje administracyjne. Blaski i cienie, red. M. Stahl, R. Lewicka, M. Lewicki, Warszawa 2011, s. 17-18.

53 J. Malanowski, Pojęcie i koncepcje odpowiedzialności administracyjnoprawnej, [w:] Współczesne zagadnienia prawa i procedury administracyjnej. Księga jubileuszowa dedykowana Prof. zw. dr hab. Jackowi M. Langowi, red. M. Wierzbowski et al., Warszawa 2009 , s. 172. 
cyjnoprawna odpowiedzialność, będąc kategorią szerszą, zawiera w sobie pojęcie sankcji, a materia związana z uchyleniem przez pozwolenie na broń ogólnego zakazu dostępu do broni palnej ${ }^{54}$ leży w sferze zainteresowania prawa zarówno administracyjnego, jak i karnego.

\section{Bibliografia}

Błaś A., Prawne formy dziatania administracji publicznej, [w:] Prawo administracyjne, red. J. Boć, Wrocław 2010.

Chochorowska P., Zwiazanie organu administracji orzeczeniem sądu karnego, „Przegląd Prawa Publicznego" 2013, nr 7-8.

Hanausek T., Problem „,niebezpieczności” broni palnej, „Państwo i Prawo” 2001, nr 6.

Jancewicz R., Niewiński L., Odpowiedzialność karna na tle art. 263 k.k. „Wojskowy Przegląd Prawniczy" 2005, nr 1.

Kotowski W., Kurzępa B., Komentarz do niektórych przepisów ustawy o broni i amunicji, [w:] eidem, Wykroczenia pozakodeksowe. Komentarz, wyd. 2, Warszawa 2008.

Kurzępa B., Ustawa o broni i amunicji. Komentarz, Warszawa 2010.

Kurzępa B., Glosa do wyroku TK z dnia 18 grudnia 2013 r., „Prokuratura i Prawo” 2015, nr 7-8.

Maj S., Ustawa o broni i amunicji. Komentarz, Warszawa 2010.

Malanowski J., Pojęcie i koncepcje odpowiedzialności administracyjnoprawnej, [w:] Wspótczesne zagadnienia prawa i procedury administracyjnej. Księga jubileuszowa dedykowana Prof. zw. dr hab. Jackowi M. Langowi, red. M. Wierzbowski, J. Jagielski, A. Wiktorowska, E. Stefańska, Warszaw 2009.

Mikowski Ł., Organy ochrony środowiska w systemie bezpieczeństwa społeczności lokalnych, [w:] Organ administracji publicznej w systemie bezpieczeństwa społeczności lokalnych, red. J. Boć, Ł. Mikowski, Wałbrzych 2016.

Mikowski R., Kilka uwag o podstawach prawnych ograniczeń dostęu do broni palnej w Polsce, „Przegląd Prawa i Administracji” 115, 2018.

Mikowski R., Kilka uwag o prawnych formach dziatania administracji w zakresie dostępu do broni palnej, [w:] Administracja publiczna pod rządami prawa. Księga pamiątkowa z okazji 70-lecia urodzin prof. zw. dra hab. Adama Btasia, red. J. Korczak, Wrocław 2016.

Muller A., Przestepstwo porzucenia broni palnej $i$ amunicji, „Wojskowy Przegląd Prawniczy" 2017, nr 3.

Opaliński B., Rogalski M., Szustakiewicz P., Ustawa o policji. Komentarz, Warszawa 2015. Podsiedlik P., Zagadnienia administracyjno-prawne posiadania broni palnej w Polsce. Charakterystyka prawa posiadania broni palnej, Katowice 2010.

${ }^{54}$ P. Ruczkowski, Decyzja w sprawie pozwolenia na broń, „Przegląd Prawa Publicznego" 2012, nr 1, s. 6-24. 
Prawo administracyjne, red. J. Boć, Wrocław 2010.

Rejmaniak R., Obowiqzek zawiadomienia o utracie broni palnej, „Prokuratura i Prawo” 2017, nr 5.

Rejmaniak R., Pojęcie broni palnej, „Prokuratura i Prawo” 2018, nr 4.

Rogalski M., Odpowiedzialność karna a odpowiedzialność administracyjna, „Ius Novum" 2014, nr 1.

Ruczkowski P., Decyzja w sprawie pozwolenia na broń, „Przegląd Prawa Publicznego” 2012, $\mathrm{nr} 1$.

Stahl M., Sankcje administracyjne - problemy węzłowe, [w:] Sankcje administracyjne. Blaski i cienie, red. M. Stahl, R. Lewicka, M. Lewicki, Warszawa 2011.

Ura E., Pieprzny S., Postępowanie w sprawach wydawania pozwoleń na broń palna, [w:] Kodyfikacja postępowania administracyjnego na 50-lecie K.P.A., red. J. Niczyporuk, Lublin 2010.

Zimmermann J., Prawo administracyjne, Warszawa 2014.

\section{Conditions of liability for the breach of obligations under a firearms licence}

Summary

The article presents general issues related to the conditions of legal liability for exceeding the rights and violation of obligations related to the authorisation of firearms, under the provisions governing access to firearms in Poland. The study includes both conditions for administrative liability and elements of criminal law regulation, which should be seen here as a supporting method that determines the issue in question. The Act of 21 May 1999 on firearms and ammunition, together with selected executive acts, was subjected to a synthetic analysis. The overall considerations include the types of legal liability in situations of the infringements in question; however, this part of the analysis is supplementary to the description of the causes of liability.

Keywords: firearms licence, firearms, possession of firearms, firearms safety. 